\title{
THE EFFECTIVENESS OF PSYCHOLOGICAL SKILLS TRAINING PROGRAM ON NETBALL SHOOTING PERFORMANCE
}

\author{
Jamatul Shahidah Shaari ${ }^{1}$, Lim Boon Hooi ${ }^{2 *}$, and Siswantoyo ${ }^{3}$ \\ ${ }^{1,2}$ Centre for Sport and Exercise Sciences, University of Malaya, Malaysia \\ ${ }^{3}$ Sport Science Faculty, Yogyakarta State University, Indonesia \\ *e-mail: lboonhooi@um.edu.my
}

\begin{abstract}
The study was aimed to investigate the effect of Psychological Skills Training Program on netball shooting performance. The experimental method was used on three groups of an 8-week intervention: combination of diaphragmatic breathing and imagery, plus physical practice (G1); combination of DB and self-talk, plus physical practice (G2); and control group which have physical practice only (G3). A SPANOVA was conducted to assess the impact of all groups on shooting performance across the two time periods. The main effect comparing the two treatments and a control group was significant, $p<.001$. Post hoc Tukey test differ significantly at $p<.05$. However, the G2 was not significantly different from the G3. The results indicated that netballers of different skill used of PST, either G1 or G2 were found to improve the netball shooting performance. It was also showed that G1 has better netball shooting performance rather than G2 and G3. As to highlighting, that the principles and practical applications of these most basic psychological skills can be taught in easier ways and probably in a relative short period of time among youth athletes.
\end{abstract}

Keywords: psychological skills training, imagery, self-talk, diaphragmatic breathing, netball shooting

\section{EFEKTIVITAS PROGRAM PSYCHOLOGICAL SKILL TRAINING PADA KETERAMPILAN TEMBAKAN NETBALL}

\begin{abstract}
Abstrak: Penelitian ini bertujuan untuk mengetahui pengaruh Program Psychological Skills Training (PST) terhadap keterampilan tembakan netball. Metode eksperimental digunakan pada tiga kelompok intervensi 8 minggu: kombinasi pernapasan diafragma dan imageri ditambah latihan fisik (G1); kombinasi pernapasan diafragma dan self-talk ditambah latihan fisik (G2); dan kelompok kawalan yang hanya menjalani latihan fisik (G3). SPANOVA dilakukan untuk menilai dampak dari semua kelompok terhadap keterampilan tembakan selama dua kali. Efek utama membandingkan dua perlakuan dan kelompok kontrol adalah signifikan, $p<.001$. Post hoc Tukey test juga mengalami perbedaan yang signifikan pada $p<$ .05. Namun, G2 tidak jauh berbeda dari G3. Hasil menunjukkan bahwa terdapat perbedaan keterampilan dari pemain netball dengan latihan PST, baik G1 atau G2 ditemukan peningkatkan keterampilan tembakan netball. Selain hal tersebut, hasil menunjukkan bahwa G1 lebih baik kemampuan tembajan netball dari pada G2 dan G3. Sebagai hasil yang paling disoroti adalah bahwa prinsip-prinsip dan aplikasi praktis dari keterampilan psikologis tersebut dapat diajarkan dengan cara yang lebih mudah dan mungkin dalam waktu yang relatif singkat kepada para atlet remaja.
\end{abstract}

Kata Kunci: psychological skills training, imagery, self-talk, pernapasan diafragma, tembakan netball 


\section{INTRODUCTION}

As all other ball games, scoring is the most important characteristic for the competitive success of a netball team (Navin, 2012). A netball team consists of seven players on the court at one time. Each position has different court restrictions and roles within match play, which is demanding the shooting performance of the two players called Goal Shooter and Goal Attack in defining the goal (Davidson \& Trewartha, 2008). Open skill such as netball shooting occur in a changing, and predictable environment such need to regularly move and adapt with different shooting distance aiming to the basket (Stoker et al., 2017). As a player, she tended to demonstrate few repetitions of movement activities and demonstrated least time walking, jogging and running, and greatest percentage of time standing (Davidson \& Trewartha, 2008). Therefore, training should be tailored to suit the needs and capabilities of particular players (Fox, Spittle, Otago, \& Saunders, 2013). Various performance indicators have been used to try to understand the psychological demand of training (Hegazy, Sherif, \& Houta, 2015).

Psychological aspects may influence the results, for example anxiety prior to competition (Fernández-Fernández, Boullosa, Sanz-Rivas, Abreu, Filaire, \& Mendez-Villanueva, 2015) or during daily event (Garza \& Ford, 2009) could cause rise in heart rate; or the visualization and concentration-attention control during the task completion could cause the performance of motor skills (Hegazy et al., 2015); or the relaxation exercise was used to gain a relaxed state so that the affirmation statements could be used in conjunction with relaxation during the preparation phase of a physical activity (Rogerson \& Hrycaiko, 2002); or could be used during the activity itself (Fraser, Steffen, \& Elfessi, 2001). Thus, it is very common that the main emphasize is to develop one's performance through mental training (Weinberg \& Gould, 2014). The argument is whether those mental preparation strategies could be effectively works, either single or a combination of techniques (Weinberg, Chan, \& Jackson, 1983).

One general definition describes the mental preparation strategy known also as psychological skills training (PST), as the "systematic and consistent practice of mental or psychological skills for the purpose of enhancing performance, increasing enjoyment, or achieving greater sport and physical activity selfsatisfaction" (Weinberg \& Gould, 2014). In other words, psychological skills are developmental targets that are addressed through training of psychological techniques (Vealey, 1988). Gardner (2009) added that PST is used to ensure that individuals attain high-level performance in sports through honing and applying necessary psychological skills. A calm mental state, the rhythm of preparation, training, and lack of pressure were the major factors contributing to the ability to maintain control or successful selfregulation (Sun \& Wu, 2011).

Weinberg and Gould (2014) responded that the PST program was effective to improve athletic performance and success. It was either with one single skills like self-talk training program such soccer skills (Johnson, Hrycaiko, Johnson, \& Halas, 2004), swimming backstroke (Zetou, Nikolaos, \& Evaggelos, 2014), cycling time trial (Barwood, Corbett, Wagstaff, McVeigh, \& Thelwell, 2015), or imagery training program such netball shooting (Fowler, 2010; Halim \& Ismail, 2016; Wakefield \& Smith, 2009), soccer passing (Seif-Barghi, Kordi, Memari, Mansournia, \& Jalali-Ghomi, 2012), soccer free kick accuracy (Hallsson, 2013), volleyball serve (Velentzas, Heinen, \& Schack, 2011), basketball free throw shooting (Samis-Smith, 2015) proven interesting significant results towards athletes performance, or the use of 
package approach - imagery, goal setting, and variations of self-talk used in Blakeslee \& Goff (2007), Wolframm \& Micklewright (2011), Kerkez, Kulak, \& Aktas (2012) and Montgomery, Ross, Perry, \& Hansen (2017). Interestingly, even with large numbers of interventions provide by the researchers, there is still lack of information on the comparison study between different combinations of mental strategy based on the assessment on the same task-performance.

When athletes have too much energy or anxiety, relaxation strategies are often helpful (Pineschi \& Di Pietro, 2013) and one of key skill and happens quickly is diaphragmatic breathing (Fraser et al., 2001). When athletes are too low in energy, they often feel tired and flat and may suffer a "let down" (Loehr, 1994). Therefore, it enables increase the ability to concentrate largely in combination with concentration, imagery or self-talk prior to practice (Harris \& Harris, 1984). Vealey and Forlenza (2015) describe imagery as "using one's sense to create or re-create an experience in the mind". This technique can be used by athlete with any cognitive strategy such as to use it effectively. Few of the literature is on using imagery in mental skill training with few controlled studies that get at how imagery works (Glynn, Gilbert, \& Lewis, 2013; Smith, Wright, Allsopp, \& Westhead, 2007) and what might make imagery more effective (Hallsson, 2013).

The relaxation techniques are skills that can be learned while some of these techniques work better for one athlete than another. The most important contribution that relaxation presents is how to regulate arousal such that the athlete does not overcharge his or her system. For example, sometimes during practice, instead of trying harder, the athlete need only relax and just let the situation naturally unfold. Putting too much effort into skill execution is almost always counterproductive. Frequently, when a player is having trouble learning a new skill, taking a few minutes out to relax such practicing the diaphragmatic breathing in combination with imagery - will be more productive than repeating the skill over and over when one is tense, fatigued, or not concentrating (Harris \& Harris, 1984).

As one of the cognitive strategy that been combine with imagery by several researchers is self-talk as self-give instructions; reinforce or interpret thoughts, feeling or actions; or carry on an internal dialogue within oneself. Whilst there is evidence in the use of imagery and self-talk independently of one another, it might be possible that they also cause preferences for the use of one strategy rather than the other to be formed. For example, previous research has revealed that athletes tend to place more emphasis on the use of imagery as a pre-competitive strategy (Munroe, Giacobbi, Hall, \& Weinberg, 2000; Weinberg, 2003) and self-talk as a strategy to be used during competition (Gammage, Hardy, \& Hall, 2001; Hardy, Hall, \& Hardy, 2005). Moreover, it has been suggested that selftalk may lend itself better to use during competition than imagery, as it is a quicker and easier strategy to employ (Hardy et al., 2005).

However, as to make a comparison there were findings suggested the combination of imagery with relaxation and/or self-talk could also produce the positive result in enhancing performance (Cumming, Nordin, Horton, \& Reynolds, 2006; Vealey, 1986). In addition, a number of research studies have demonstrated that imagery combined with relaxation is more effective than imagery alone (Hallsson, 2013; Weinberg, Seabourne, \& Jackson, 1981). It make a great sense since it is usually suggested that relaxation enhances the clarity of the athlete's imaging (Harris \& Harris, 1984). Accordingly, self-talk was hypothesized can help the athlete increase the self-confidence when combining with imagery. However, 
Cumming et al. (2006) revealed that combination of these two had no effect on self-confident but the self-talk may helping on cues while imagine. While, past research has demonstrated the positive effects of single used of focus self-talk for improving performance such in basketball (Chroni, Perkos, \& Theodorakis, 2007), tennis (Van Raalte, Cornelius, Brewer, \& Petitpas, 2006) and throwing-and-jumping events (Goudas, 2006) performance.

For some reason the literature indicates that many coaches exclude psychological skills training (PST) from the training and preparation of their athletes (Freitas, Dias, \& Fonseca, 2013a; Grobbelaar, 2007) and a lack of knowledge about PST (Freitas, Dias, \& Fonseca, 2013b; Grobbelaar, 2007). However, there have been possible explanations from athletes' point of view for the need of development and implementation of PST including the awareness to improve poor psychological preparation for competitions (van Den Heever, Grobbelaar, \& Potgieter, 2007). Another possible explanation reported that more than $50 \%$ of the youth athletes claimed that they "never heard or do not know" about meditation, autogenic training, progressive muscular relaxation, concentration training and imagery (Ong, 2004). All of these feedbacks illustrate the importance of mental strategies in helping athletes improve their performance in their respective sports. To date, countless studies have proven the effectiveness of psychological strategies to improve athletes' performance and yet the number of research involved in netball and Malaysia contexts is still small. Such a trend has created a general concern of whether the huge number of PST programs been designed has any way could be applied to assess shooting-task performance among netball shooters. Thus, the aim of this study was to determine the effectiveness of PST program in shooting-task performance on netball shooters.

\section{METHODS}

\section{Participants}

Forty-six netball athletes' age between 13 to 16 years old from Kuala Lumpur Sports School participated in the present study. The subjects were recruited as not to be involved in official competitions such as Malaysia Sport (SUKMA) or Malaysia School Sports Council Sport (MSSM) during the intervention period. The athletes not an elite standard and none of them reported having any experience of formal PST program. The study was performed after approvals of the University's Research Ethics Committee was obtained, and followed by having the sanctions from Ministry of Education Malaysia (MOE) and Kuala Lumpur Federal Territory Education Department. As the subjects were under 18 years of age, subjects along with their parents and coaches were provided information about the study.

\section{Procedures}

The subjects were recruited to three groups: Group $1-$ combination of diaphragmatic breathing and imagery, plus physical practice (DB and IM, + PP) with $n=16$; Group $2-$ combination of diaphragmatic breathing and self-talk, plus physical practice (DB and ST, + PP) with $n=15$; Group 3 - physical practice (PP) with $n=15$. The subjects who achieved a criterion of equal to or less than 36 of the Vividness of Movement Imagery Questionnaire-2 (VMIQ-2) subscales were recruited as Group 1 members. The first 16 out of 46 subjects were therefore recruited into the Group 1, while, the remaining 30 subjects were equally divided randomly into the Group 2 and Group 3. The intervention groups - Group 1 and Group 2 performed three times per week with 30 minutes of PST and followed by 30 minutes of PP per session at different days 
for eight weeks that in total was 24 sessions for each group. Except, the control group - Group 3 which only did for 30 minutes of PP in a session. No information about the purpose of the study was given to the subjects until they completed the experiment.

\section{The Intervention Schedule}

In familiarization phase, the subjects in Group 1 and Group 2 had a session in which they received instruction and training on how to perform the PST interventions, respectively. The subjects were familiarized with what will be done, and what is expected from them could become grateful assistance to subject who has never practiced shooting even though they are netball players. The protocol of physical practice (PP) session also was explained and the subjects received instruction on how to perform shooting during the sessions scheduled for them. Due to varying levels of shooting experience and their ability, the subjects performance considering only after they were familiarize with the expected tasks to maintain consistency in the following 8 weeks intervention period. The duration of each session for both intervention groups was lasted for 30 minutes session - 10 minutes with DB training and 20 minutes with either IM training or ST training. As the subjects are considered new to pyschological skills techniques, training is carried out as they lie down because it will be very relaxing and can help them more fully focus on their breathing, images or phrases that are required. After completing the 30 minutes PST session, the subjects were continued with 30 minutes of PP.

\section{$D B$ and IM training}

The subjects participated in the DB while lying in a quiet and comfortable room. The researcher lead the session and read the relaxation script in about 10 minutes, while the research assistance was utilized to monitored the subjects. The subjects were reminded that they should enable to fell the relaxation after they finished with the breathing exercise. The subjects were then asked to continue laydown and continue with the instructional imagery script that was read out to them for another 20 minutes. As short as possible, remind the subjects how exactly the technique can incorporated into their PP later.

\section{$D B$ and ST training}

The purpose of performing DB before conducting ST training is the same as in conducting for Group 1. The subjects participated in the DB while lying in a quiet and comfortable room and lasted approximately 10 minutes. While the researcher led the session and read the script of relaxation the research assistance was utilized to monitored the subjects. The subjects were then asked to continue laydown and continue with the self-talk script that was read out to them for another 20 minutes. The steps are simplify by address each or more than one steps in making a successful shooting to four components which can gives a single cue word 'check', 'aim', 'flick' and 'followthrough' to instruct where they had to focus their attention for shooting. The selftalk phrases and self-talk instruction cues that need to be self-generated by the subject should be recite just before they continue with their PP afterwards.

\section{Physical Practice (PP)}

The basic part of this shooting task in allowing a subject to perform a shooting was refer to the technical parts recommended by Navin (2012). The subject had performed 20 trials in the first round at a distance of 1.5 meters and 3.0 meters from the post and be given a break for 3 minutes before continuing 20 trials in the second round for the other distance. The subjects must perform according to the rules of the game, in which they are allowed to hold the ball for only 3 seconds 
(before shooting) and shall obey the Footwork Rule. After each attempt made by the subject whether it is successful or unsuccessful, the rebound ball is taken by the feeder (research assistant). Right after that, the feeder is within a distance of 0.9 meters acting as a defender by raising both hands.

\section{Measures}

This study was an experimental design involved three phases:

Phase 1: A baseline phase that the researcher needs to indicate the imagery ability of the subjects. Then, the subjects were divided into three groups. The data was collected during pretest activity.

Phase 2: The intervention phase, lasting for eight weeks for the intervention groups - Group 1 and Group 2, and no intervention was provided to the control group - Group 3.

Phase 3: The post-intervention phase, the data was collected on the last session.

\section{Vividness of Movement Imagery Questionnaire-2 (VMIQ-2)}

The athletes were asked to answered VMIQ-2 to indicate their imagery ability (Roberts, Callow, Hardy, Markland, \& Bringer, 2008). The subjects who achieved a criterion of equal to or less than 36 of the VMIQ-2 subscales were recruited as Group 1 members (i.e. DB and IM, + PP). The criterion indicated that their imagery ability was at least moderately clear and vivid (Lawrence, Callow, \& Roberts, 2013; Roberts et al., 2008). Whereas, the remaining thirty subjects were equally divided randomly into the experimental Group 2 (i.e. DB and ST, + PP) and Group 3 (i.e. PP only).

\section{Netball Shooting Task}

Even though there was several shooting style across the world, but the preferred technique has changes from a two-handed shot to the one-handed high release shot known as Australian shooting style was selected for this study (Lim, Choo, Safee, \& Tan, 2011; Shakespear \& Caldow, 2009). Two assessors recorded each attempt using the scoring scale which 1 point if the ball goes directly into net and 0 point if the ball do not goes into net. Shooting task performance was measured by summing the scores for 40 attempts. The summation scores range from 0 to 40 points.

\section{RESULTS AND DISCUSSION \\ Results}

Kolmogorov-Smirnov and the Levene's test showed that the assumption of normality was met within each group. The Levene's test and Box's Test of Equality of covariance matrices were not significant value $(p>.05)$ and thus, parametric tests can be applied. During pretest, Group 1 (i.e. DB and IM, + PP) had the same mean score with Group 2 (i.e. DB and ST, + PP) (mean $=4.00)$. Group 3 as control group (mean $=3.20$ ) has the lowest mean score. However, for the post-test, the mean score for Group 1 (mean $=13.94)$ was higher than Group 2 (mean $=6.87)$. The mean score for control group was remain the lowest (mean = 4.40). The graph of the profile plot illustrated in Figure 1 clearly indicated that the shooting performance for the treatment groups increase over time. However, the mean value of Group 1 outperformed the Group 2 during the posttest. Group 2 showed marginal increase of mean value during the posttest. For the control group, the mean value was increase over time; however, the increasing of the mean value of treatment groups was much better than the control group.

A split-plot analysis of variance (SPANOVA) was conducted to assess the impact of two different treatments and a control group on athletes' shooting performance score, across the two time periods of pre-post intervention. There was a significant interaction between groups and time $($ Wilks Lambda $=.612, F(2,43)=$ 
13.61, $p<.001)$. There was also a substantial main effect for time, (Wilks Lambda $=.515, F(1,43)=40.507, p<$ .001 , partial eta squared $=.485$ ) with all groups showing an increment in shooting performance score across the two time periods (Table 1).

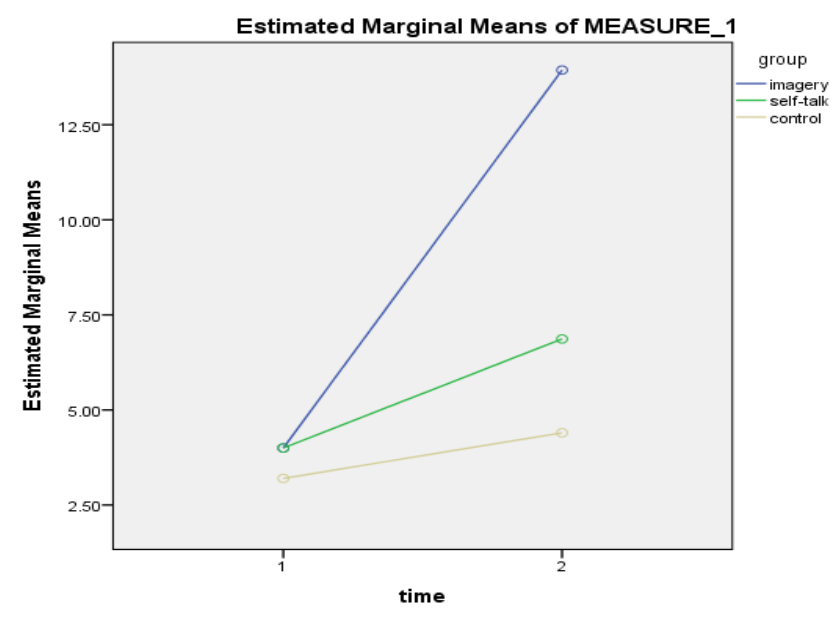

Figure 1. Profile Plots to Indicate the Pre-Test and Post-Test for Shooting Performance Means of the Three Groups Based on the Time

Table 1. Multivariate Tests

\begin{tabular}{llcccccc}
\hline Effect & Value & F & Hypothesis df & Error df & Sig. & $\begin{array}{c}\text { Partial Eta } \\
\text { Squared }\end{array}$ \\
\hline \multirow{4}{*}{ time } & Pillai's Trace & .485 & 40.507 & 1.000 & 43.000 & .000 & .485 \\
& Wilks' Lambda & .515 & 40.507 & 1.000 & 43.000 & .000 & .485 \\
& Hotelling's Trace & .942 & 40.507 & 1.000 & 43.000 & .000 & .485 \\
& Roy's Largest Root & .942 & 40.507 & 1.000 & 43.000 & .000 & .485 \\
& Pillai's Trace & .388 & 13.606 & 2.000 & 43.000 & .000 & .388 \\
time * & Wilks' Lambda & .612 & 13.606 & 2.000 & 43.000 & .000 & .388 \\
group & Hotelling's Trace & .633 & 13.606 & 2.000 & 43.000 & .000 & .388 \\
& Roy's Largest Root & .633 & 13.606 & 2.000 & 43.000 & .000 & .388 \\
\hline
\end{tabular}

Table 2. Table of Tests of Between-Subjects Contrasts

\begin{tabular}{ccccccc}
\hline Source & $\begin{array}{c}\text { Type III Sum of } \\
\text { Squares }\end{array}$ & df & Mean Square & F & Sig. & $\begin{array}{c}\text { Partial Eta } \\
\text { Squared }\end{array}$ \\
\hline Intercept & 3383.651 & 1 & 3383.651 & 183.445 & .000 & .810 \\
group & 435.299 & 2 & 217.650 & 11.800 & .000 & .354 \\
Error & 793.135 & 43 & 18.445 & & & \\
\hline
\end{tabular}

Table 3. Post Hoc Tests: Multiple Comparisons

\begin{tabular}{lcccc}
\hline \multirow{2}{*}{ Group } & $\begin{array}{c}\text { Mean } \\
\text { Difference }\end{array}$ & Sig. & \multicolumn{2}{c}{ 95\% Confidence Level } \\
\cline { 5 - 5 } G1 (DB \& IM, + PP) and & 3.5354 & .002 & 1.3343 & 5.7365 \\
G2 (DB \& ST, + PP) & & & & \\
G1 (DB \& IM + PP) and & 5.1688 & .000 & 2.9677 & 7.3698 \\
G3 (PP only) & & & & \\
G2 (DB \& ST, + PP) and & 1.6333 & .148 & -.6030 & 3.8697 \\
G3 (PP only) & & & & \\
\hline
\end{tabular}


and a control groups was significant, $F(1,43)=11.800, p<.001$, with partial eta squared $=.354$. Post hoc Tukey test indicated that the Group 1 and Group 2 differ significantly at $p<.05$ and the Group 1 and Group 3 differ significantly at $p<.05$. However, the Group 2 was not significantly different from the Group 3. The summarization of mean difference showed that the subjects of different treatment from Group 1 and Group 2 were found effectively in increasing shooting performance. It was also showed that the Group 1 has better shooting performance rather than Group 2 and the Group 3 (Table 3).

\section{Discussion}

The purpose of this study was to investigate the influence of Group 1, Group 2 and Group 3, specifically expecting result from the intervention groups on the improvement of the netball shooting-task performance. The athletes of different treatment from Group 1 and Group 2 were found effectively in increasing shooting performance. It was also showed that the Group 1 has better shooting performance rather than Group 2 and the Group 3. Given the goal as to increase the performance, some findings claimed that without the use of other mental strategy and follow by PP, IM or ST alone could also fulfill the goal (Boubouki \& Perkos, 2014; Fowler, 2010; Kolovelonis, Goudas, \& Dermitzaki, 2011; Wakefield \& Smith, 2009). Fortunately, this study, Aghdasi and Touba (2012), and Hemayattalab and Movahedi (2010) revealed that the combination of PP leads to better result than separate practice. This may explained by the fact that young athlete may feel that their body well by having the PP and they understand the importance of focusing on the PST techniques that they been taught. Probably, they may felt the improvement on the relaxation mode that can gain in shorter period of time, or able to lessen the pressure which accompanying them during the practices by having either, IM or ST.

Some findings revealed on the effectiveness of PST program among adult athletes which contain almost similar program with these studies (Fowler, 2010; Peluso, Ross, Gfeller, \& LaVoie, 2005; Thelwell, Weston, \& Greenlees, 2010). Nevertheless, Capranica and MillardStafford (2011) had investigate the effect of PST with young athletes, which found positive results for its effects on performance. Interestingly, most of them started training and participating in competitions early in their childhood. For example, this perspective was supported by Frick, Daum, Wilson and Wilkening (2009) which the finding proved that the effectiveness of IM training in adult athletes cannot be transferred one-to-one to young athletes because there is a difference with respect to motor skills. Some more, this is reinforced with insight that the association between motor imagery ability and motor performance may get stronger with age (Caeyenberghs, Tsoupas, Wilson, \& Smits-Engelsman, 2009). This study may promote comprehensive PST program on future study promoting motor learning in young athletes from different kind of sports and may consider on under some conditions such as kinesthetic experiences to the judgement task.

The practical part in this study was provided basic knowledge from the practices of IM and ST (cognitive strategy) in separate intervention with each of them was used just after DB (somatic strategy). Subjects were thought three easier PST techniques to use during their practices. Reason for that might be that these are more interesting PST techniques for younger athletes. In this study, it was expected that athletes may had some difficulties to find out right state of mind and make it work but after few repetitions, they were able to use ST than the IM. Similarly, as the subjects considered as a 
"beginner" in practicing the self-talk, they are prompted to think and memorize the self-talk instruction cues to get a sense of how to perform the shooting task. Hence, the subjects were asked to consolidate the acquired skill from the trigger cue words into their physical practices along the intervention phase with a steady, spontaneous and deliberate pace. Even though, imagery was easier too but it may needs more time to feel comfortable for practices than self-talk. This was supported by Peluso et al. (2005) that who engaged in less than ten hours of athletic activities per week preferred self-talk strategy.

However, this study reported that the DB and IM group was better than DB and ST group though the subjects were engaged in three hours-per-week programs, equally for both techniques. It was probably because of the recruitment basic on DB and IM group was based on the average criteria on their imagery ability (Lawrence et al., 2013; Roberts et al., 2008). Specifically, It could be claim that the Group 1 intervention can be potentially use and should be replicate by other researcher since the result of this study proven was not interfere by the imagery ability of the athletes.

\section{CONCLUSION}

Key findings included that either the athletes may use both type of intervention the combination of DB and IM, or DB and ST probably with the reason of using breathing technique as a strategy to overcome stress and getting calmer and gaining focus before continue with either IM or ST technique. Therefore, the athletes are able to focus more in their way to perform the shooting task. Interestingly, probably the function of IM and ST were found to serve for different purpose. The IM use to plan for making a successful shot, while, the ST use to create and maintain the psychological state while making a successful shot. An attempt was made to conclude in a clear and concise fashion the efficacy of a practical PST program that might provide readily useable information for coaches, athletes and researchers.

The program could be tested with athletes of different levels including college athletes. It is also important to note that the age of the athlete could impact his or her understanding of the intervention techniques, as he or she may have different levels of mental capacity. Hence, future work should assess the effect of age in intervention implementation. As to highlighting, that the principles and practical applications of the most basic psychological skills can be taught in easier ways and probably in a relative short period of time among youth athletes. In summary, athletes should work with the strategy that they are most comfortable with. This is to ensure that their experience in applying the strategy will be as pleasant as possible. Therefore, coaches should be extra careful when administering the PST program on their athletes, as the athletes might not be using the combination of strategies as effectively as other strategy combinations.

\section{REFERENCES}

Aghdasi, M. T., \& Touba, N. (2012). The effects of instructional self-talk on girl's performance, retention and transfer of dart throwing in late childhood and adolescence. Journal of Physical Education and Sport, 12(3), 391-397.

doi: 10.7752/jpes.2012.03058.

Barwood, M. J., Corbett, J., Wagstaff, C. R. D., McVeigh, D., \& Thelwell, R. C. (2015). Improvement of 10-km time-trial cycling with motivational self-talk compared with neutral selftalk. International Journal of Sports Physiology and Performance, 10(2), 166-171. doi: 10.1123/ijspp.20140059 . 
Blakeslee, M. L., \& Goff, D. M. (2007). The effects of a mental skills training package on equestrians. Sport Psychologist, 21(3), 288-301.

Boubouki, S., \& Perkos, S. (2014). The effects of instructional self-talk on female volleyball performance during training. Inquiries in Sport \& Physical Education, 12(2), 170-175.

Caeyenberghs, K., Tsoupas, J., Wilson, P. H., \& Smits-Engelsman, B. C. (2009). Motor imagery development in primary school children. Developmental Neuropsychology, 34(1), 103-121. doi: $10.1080 / 87565640802499183$.

Capranica, L., \& Millard-Stafford, M. L. (2011). Youth sport specialization: how to manage competition and training? International Journal of Sports Physiology and Performance, 6(4), 572-579.

Chroni, S., Perkos, S., \& Theodorakis, Y. (2007). Function and preferences of motivational and instructional self-talk for adolescent basketball players. Athletic Insight: The Online Journal of Sport Psychology, 9(1), 19-31.

Cumming, J., Nordin, S. M., Horton, R., \& Reynolds, S. (2006). Examining the direction of imagery and self-talk on dart-throwing performance and self efficacy. Sport Psychologist, 20(3), 257-274. doi: 0.1123/tsp.20.3.257

Davidson, A., \& Trewartha, G. (2008). Understanding the physiological demands of netball: A time-motion investigation. International Journal of Performance Analysis in Sport, 8(3), 1-17. doi: 10.1080/24748668.2008.11868443.
Fernández-Fernández, J., Boullosa, D., Sanz-Rivas, D., Abreu, L., Filaire, E., \& Mendez-Villanueva, A. (2015). Psychophysiological stress responses during training and competition in young female competitive tennis players. International Journal of Sports Medicine, 36(01), 22-28. doi: $10.1055 / \mathrm{s}-0034-1384544$.

Fowler, H. (2010). The effects of psychological skills training on shooting accuracy in university netball players. Journal of Sports Therapy, 3(3), 13-17.

Fox, A., Spittle, M., Otago, L., \& Saunders, N. (2013). Activity profiles of the Australian female netball team players during international competition: Implications for training practice. Journal of Sports Sciences, 31(14), 1588-1595. doi: 10.1080/02640414.2013.792943.

Fraser, R., Steffen, J., \& Elfessi, A. (2001). The effect of relaxation training on indoor rock climbing performance. Physical Educator, 58(3), 134.

Freitas, S. P., Dias, C. S., \& Fonseca, A. M. (2013a). Elite portuguese soccer players' use of psychological techniques: where, when and why. Journal of Human Sport and Exercise, $8(3)$, 847-860. doi:10.4100/jhse.2013.83.10.

Freitas, S. P., Dias, C. S., \& Fonseca, A. M. (2013b). What do Coaches Think about Psychological Skills Training in Soccer? A Study with Coaches of Elite Portuguese Teams. International Journal of Sports Science, 3(3), 81-91. doi: 10.5923/j.sports.20130303.04. 
Frick, A., Daum, M. M., Wilson, M., \& Wilkening, F. (2009). Effects of action on children's and adults' mental imagery. Journal of Experimental Child Psychology, 104(1), 34-51. doi: 10.1016/j.jecp.2009.01.003.

Gammage, K. L., Hardy, J., \& Hall, C. R. (2001). A description of self-talk in exercise. Psychology of Sport and Exercise, 2(4), 233-247. doi: 10.1016/S1469-0292(01)00011-5.

Gardner, F. L. (2009). Efficacy, mechanisms of change, and the scientific development of sport psychology. Journal of Clinical Sport Psychology, 3(2), 139-139. doi: 10.1123/jcsp.3.2.139.

Garza, L., \& Ford, S. J. (2009). Implementing a Breathing Technique to Manage Performance Anxiety in Softball. Sport Journal, 12(2), 1-1.

Glynn, B. A., Gilbert, J. N., \& Lewis, D. K. (2013). Psychological Skills Training and Self-efficacy: The UNIFORM approach with college-age swim exercisers. Athletic insight, 5(1), 93-111.

Goudas, M. (2006). The effects of self-talk on throvving and jumping events performance. Hellenic Journal of Psychology, 3, 105-116.

Grobbelaar, H. W. (2007). A survey of South African provincial netball coaches' opinions, abilities and limitations regarding mental skills training. South African Journal for Research in Sport, Physical Education \& Recreation (SAJR SPER), 29(2), 27-39. doi: 10.4314/sajrs.v29i2.25965.
Halim, N. A. A., \& Ismail, M. (2016, March). The effects of practice in mind (PIM) training on netball standing shooting performance. Paper presented at the Proceedings of the 4th Global Summit on Education, Kuala Lumpur, Malaysia.

Hallsson, H. (2013). Is relaxation prior to imagery really beneficial; effects on imagery vividness, and concentration, and performance. (Electronic Thesis). Retrieved from https://etd.ohiolink.edu/.

Hardy, J., Hall, C. R., \& Hardy, L. (2005). Quantifying athlete self-talk. Journal of Sports Sciences, 23(9), 905-917. doi: 10.1080/02640410500130706.

Harris, D. V., \& Harris, B. L. (1984). The athlete's guide to sports psychology: Mental skills for physical people (Vol. 1). New York, NY: Leisure Press.

Hegazy, K., Sherif, A. M., \& Houta, S. S. (2015). The effect of mental training on motor performance of tennis and field hockey strokes in novice players. Advances in Physical Education, 5(02), 77 . doi: 10.4236/ape.2015.52010.

Hemayattalab, R., \& Movahedi, A. (2010). Effects of different variations of mental and physical practice on sport skill learning in adolescents with mental retardation. Research in developmental disabilities, 31(1), 8186. doi: 10.1016/j.ridd.2009.07.022.

Johnson, J. J., Hrycaiko, D. W., Johnson, G. V., \& Halas, J. M. (2004). Self-talk and female youth soccer performance. Sport Psychologist, 18(1), 44-59. 
Kerkez, F., Kulak, A., \& Aktas, Y. (2012). Effects of specific imagery and autogenic relaxation combined intervention on soccer skill performance of young athletes in Turkey. Scottish Journal of Arts, Social Sciences and Scientific Studies, 3(1), 53-67.

Kolovelonis, A., Goudas, M., \& Dermitzaki, I. (2011). The effects of instructional and motivational self-talk on students' motor task performance in physical education. Psychology of Sport and Exercise, 12(2), 153-158. doi:

10.1016/j.psychsport.2010.09.002.

Lawrence, G., Callow, N., \& Roberts, R. (2013). Watch me if you can: imagery ability moderates observational learning effectiveness. Frontiers in human neuroscience, 7(522), 1-7. doi: 10.3389/fnhum.2013.00522.

Lim, C. S., Choo, K. L., Safee, R., \& Tan, C. Z. (2011). Modul latihan sukan untuk guru penasihat kelab sukan sekolah (bolajaring - sekolah menengah). Retrieved from http://www.moe.gov.my/v/1-murid-1sukan-view?id=2124\&.

Loehr, J. E. (1994). The new toughness training for sports: Mental, emotional, and physical conditioning from one of the world's premier sports psychologists. New York, NY: Dutton.

Montgomery, T., Ross, M., Perry, J., \& Hansen, A. (2017). The mental workout: Implementing phase 1 of the Ten-Minute Toughness mental training program. Journal of Sport Psychology in Action, 9(2), 73-82. doi: 10.1080/21520704.2017.1343213.
Munroe, K. J., Giacobbi Jr, P. R., Hall, C. R., \& Weinberg, R. (2000). The four ws of 1magery use: Where, when, why, and what. Sport Psychologist, 14(2), 119. doi: 10.1123/tsp.14.2.119.

Navin, A. (2012). Netball practices and training A practical guide for players and coaches. Marlborough, UK: The Crowood Press Ltd.

Ong, K. S. (2004). The use of sports psychological skills in Malaysian School Athletes. Paper presented at the Regional Conference on Human Performance, Kuala Lumpur, Malaysia.

Peluso, E. A., Ross, M. J., Gfeller, J. D., \& LaVoie, D. J. (2005). A comparison of mental strategies during athletic skills performance. Journal of Sports Science and Medicine, 4(4), 543-549.

Pineschi, G., \& Di Pietro, A. (2013). Anxiety management through psychophysiological techniques: Relaxation and psyching-up in sport. Journal of Sport Psychology in Action, 4(3), 181-190. doi: 10.1080/21520704.2013.820247.

Roberts, R., Callow, N., Hardy, L., Markland, D., \& Bringer, J. (2008). Movement 1magery ability: Development and assessment of a revised version of the vividness of movement 1magery questionnaire. Journal of Sport \& Exercise Psychology, 30(2), 200-221. doi: 10.1123/jsep.30.2.200.

Rogerson, L. J., \& Hrycaiko, D. W. (2002). Enhancing competitive performance of ice hockey goaltenders using centering and self-talk. Journal of Applied Sport Psychology, 14(1), 14-26. doi: 10.1080/10413200209339008. 
Samis-Smith, P. P. (2015). The use of mental imagery to reduce anxiety in female high school basketball athletes. (Doctoral dissertation, A.T. Still University of Health Sciences). Retrieved from http://search.proquest.com.ezaccess.li brary.uitm.edu.my/docview/16582497 71 ?accountid $=42518$.

Seif-Barghi, T., Kordi, R., Memari, A.-H., Mansournia, M.-A., \& Jalali-Ghomi, M. (2012). The effect of an ecological 1magery program on soccer performance of elite players. Asian Journal of Sports Medicine, 3(2), 8189. doi: 10.5812/asjsm.34703.

Shakespear, W., \& Caldow, M. (2009). Netball: Steps to success (2nd ed.). Champaign, IL: Human Kinetics.

Smith, D., Wright, C., Allsopp, A., \& Westhead, H. (2007). It's all in the mind: PETTLEP-Based 1magery and sports performance. Journal of Applied Sport Psychology, 19(1), 8092. doi: $10.1080 / 10413200600944132$.

Stoker, M., Maynard, I., Butt, J., Hays, K., Lindsay, P., \& Norenberg, D. A. (2017). The effect of manipulating training demands and consequences on experiences of pressure in elite netball. Journal of Applied Sport Psychology, 29(4), 1-15. doi: 10.1080/10413200.2017.1298166.

Sun, Y., \& Wu, X. (2011). Self-regulation of elite athletes in China. Social Behavior \& Personality: an international journal, 39(8), 10351044. doi: 10.2224/sbp.2011.39.8.1035.

Thelwell, R. C., Weston, N. J. V., \& Greenlees, I. A. (2010). Examining the use of psychological skills throughout soccer performance.
Journal of Sport Behavior, 33(1), 109127.

Van Den Heever, Z., Grobbelaar, H. W., \& Potgieter, J. C. (2007). A survey of psychological skills training in South African netball. African Journal for Physical, Health Education, Recreation and Dance, 13(3), 254266. doi: 10.4314/ajpherd.v13i3.24769.

Van Raalte, J. L., Cornelius, A., Brewer, B., \& Petitpas, A. (2006). Selfpresentational effects of self-talk on perceptions of tennis players. Hellenic Journal of Psychology, 3(2), 134-149.

Vealey, R. S. (1986). Imagery training for performance enhancement. In J. M. Williams (Ed.), Applied Sport Psychology: Personal Growth to Peak Performance (pp. 217-219). Mountain View, Canada: Mayfield.

Vealey, R. S. (1988). Future directions in psychological skills training. The Sport Psychologist, 2(4), 318-336. doi: $10.1123 /$ tsp.2.4.318.

Vealey, R. S., \& Forlenza, S. (2015). Understanding and using imagery in sport. In J. M. Williams \& V. Krane (Eds.), Applied sport psychology: Personal growth for peak performance (pp. 240-273). New York, NY: McGraw-Hill.

Velentzas, K., Heinen, T., \& Schack, T. (2011). Routine integration strategies and their effects on volleyball serve performance and players' movement mental representation. Journal of Applied Sport Psychology, 23(2), 209222.

doi: 10.1080/10413200.2010.546826.

Wakefield, C. J., \& Smith, D. (2009). Impact of differing frequencies of PETTLEP imagery on netball 
shooting performance. Journal of Imagery Research in Sport and Physical Activity, 4(1), 1-12. doi: 10.2202/1932-0191.1043.

Weinberg, R. S. (2003). The relationship between the use and effectiveness of imagery: An exploratory investigation. Journal of Applied Sport Psychology, 15(1), 26-40. doi: 10.1080/10413200305398.

Weinberg, R. S., Chan, R., \& Jackson, A. (1983). Mental preparation strategies and performance: Is a combination of techniques better than a single technique? Journal of Sports Sciences, 1(3), 211-216. doi: 10.1080/02640418308729682.

Weinberg, R. S., \& Gould, D. (2014). Foundations of sport and exercise psychology (6th ed.). Champaign, IL: Human Kinetics.
Weinberg, R. S., Seabourne, T. G., \& Jackson, A. (1981). Effects of visuomotor behavior rehearsal, relaxation, and imagery on karate performance. Journal of sport psychology, 3(3), 228-238.

Wolframm, I., \& Micklewright, D. (2011). The effect of mental skills training on non-elite dressage performance. Journal of Veterinary Behavior: Clinical Applications and Research, 6(5), 298-299. doi: 10.1016/j.jveb.2011.05.019.

Zetou, E., Nikolaos, V., \& Evaggelos, B. (2014). The effect of instructional self-talk on performance and learning the backstroke of young swimmers and on the perceived functions of it. Journal of Physical Education and Sport, 14(1), 27-35. doi: 10.7752/jpes.2014.01005. 